\title{
THE BAHAMAS IN INTERNATIONAL AFFAIRS
}

\author{
Hon. James B. Moultrie \\ Parliamentary Secretary \\ Ministry of Foreign Affairs
}

Distinguished Ladies and Gentlemen:

I am Indeed honoured to have been invited to address you tonight on "The Bahamas in International Affairs". I must admit that this subject Impinges on so many areas and issues that one night could hardly do justice to the subject. Nevertheless, I have considered some of the main areas and issues of concern to us and I hope you find my treatment stimulating.

The Independence Conference on 12 th-30th December, 1972 paved the way for the Independence of The Bahamas and ultimate control of its external affairs. Independence thus created the nation state of The Commonwealth of The Bahamas, the single most important criterion to becoming an actor in International Affairs.

The Ministry of External Affairs was formalised on 7 th May, 1975 when the Ministry of External Affairs Act (No. 6 of 1975) was assented to. This Act gave the Minister of External Affairs sole responsibility for the conduct and management of external affairs as far as they appertain to the Government of The Bahamas. To facilitate this management, we have established a Mission to the United Nations - the principal forum of multilateral diplomacy, an Embassy in the United States, our giant neighbour to the north, as well as Consulates General in New York and Miami, and a High Commission in the United Kingdom. Closer home there is an Honorary Consulate in Haiti.

The Bahamas has diplomatic relations with many other countries. Among them are France, Germany (West), Mexico, Canada, Haiti, Nigeria, Cuba, the Caribbean, Israe1, Turkey, Italy and Indonesia.

The defeat of the Axis Powers in the Second World War saw the emergence of two political and military giants, the United States of America and the U.S.S.R., with their attendent spheres of influence and allies. Although they fought together in that conflict, their differences soon became critical and the cold war resulted. For many years the study of International Relations dealt with the super powers. However, the complexion of the world's political society was rapidly changing. The periad of Detente provided an atmosphere for the emergence of other issues: Human Rights, Energy and Colonialism, and Self-Determination. It also heralded the emergence of a number of small states in the International Community.

The arrival of this new group of countries with differing levels of economic development, the continuous rapid population growth, the decline in world commodity prices, the increased competition for the world's scarce econcmic resources, brought to the forefront new problems which required new and different approaches.

The Third World became a political and economic force which ultimately shifted the balance of power (i.e. voting strength) in virtually every organization in the International System. The Bahamas thus arrived on the scene at a time when the International System was saturated with problems, many of which required radical solutions.

Foreign policy is the pursuit abroad of national or domestic objectives. The process of foreign policy formulation is a serious and many times sensitive one. It entails the collection and research of information, it's analysis and evaluation and choosing the appropriate strategy to achieve the desired goals.

The cornerstone of the government's national policy include:

i) the preservation of its independence and security;

ii) to foster ordered economic growth and development;

iii) to work for peace and security of the Bahamian people; 
iv) to promote social justice; $\quad-21-$

v) to enhance the quality of life for the Bahamian people, and;

vi) to ensure a harmonious natural environment.

These objectives determine the Foreign Policy of The Bahamas, which include inter alia:-

1) That The Bahamas will continue to pursue a course of peace with its neighbours and with all nations;

2) That The Bahamas will support the right of all colonial peoples to self-determination and independence;

3) That The Bahamas will oppose the political interference of one state in another state's internal affairs;

4) That The Bahamas will work for a more equitable and stable world economic order;

5) That The Bahamas will pursue trade and cultural relations with all countries wherever and whenever such relations will encourage and enhance the social and economic development of The Bahamas;

6) That at all times, the paramount consideration in the formulation of our forelgn polfcy and in the conduct of our forelgn relations will be the economic interest and social well-being of the Bahamtan people.

In pursuit of the most fundamental objective of protecting the sovereignty and territorial integrity of The Bahamas, there have been some disagreements with other states who have their own opinions of what we are attempting to do. In the process, there have been negative reactions even from Bahamians who do not seem to appreclate what it means to protect the soverelgnty of The Bahamas.

The preservation of our fishery resources is one example of pursuing a policy which protects the interest of The Bahamas. There have been a numer of approaches made to us to permit forelgn nationals to fish in The Bahamas, including approaches from the United States and Cuba. We could not agree to allow larger countries to share in our very Iimited fishery resources. But that has been met with opposition and has led to conflicts between The Bahamas and Cuban Americans who poach in our waters. We as Bahamians have to decide whether we are to protect ourselves against violations of our laws by outsiders.
The defence of that same national interest has led to the Flamingo incident. We were protecting the interest of The Bahamas witen we were attacked by the aggressive cuban forces. That is an implication of having a national policy which we expect our neighbours and others in the international community to respect, as we do theirs.

The Immovable Properties Legislation is yet another example of the preservation of the interest of The Bahamas. Virtually every country in the world has some control over the alienation of land to foreign persons. In pursuit of this policy which seeks to protect The Bahamas for Bahamians, we are faced with opposition both from within and outside The Bahamas. And so we have had to face opposition when all we are attempting to do is protect the interest of The Bahamas. No foreign person has the fundamental right to buy Bahamian land. Similarly, no Bahamian has the fundamental right to selil The Bahamas to anyone. But all Bahamians have a solem obligation to protect The Bahamas and to preserve its independence and sovereignty.

A final example of protecting the interest of The Bahamas is manifested in the bank secrecy 1aws. We have determined years ago that it was in the good interest of The Bahamas to protect the confidentiality of our banking arrangements. In the process, however, we do not condone illegal practises; and so we have instituted laws which break bank secrecy provided the established legal procedures are followed. That too has led to certain disagreements with other states. The intention is to protect the sovereignty and independence of The Bahamas. In so doing, we subscribe to the principle of non-interference in the internal affairs of states, and only request that all other states respect our national sovereignty.

The fist major step taken by the newly independent $\mathrm{B}$ ahamas was its admission into the United Nations in September 1973, the principal organization where multilateral diplomacy is conducted. The next major step was to take action to ensure that existing relationships with states in the International System continued. Since Independence The Bahamas has joined many important organizations concerned with regulating various asnorte of fntomatianot 
relations.

Brjefiy, the major organizations which we participate in are: International Civil Aviation Organization, World Health organization, International Maritime Organization; Universal Postal Union; International Telecomunications Union; Food and Agriculture Organization; United Nations Educational, Scientific and Cultural Organization (UNESCO); World Intellectual Property Organization, (copyrights and industrial protection); The World Bank; The International Monetary Fund; Caribbean Development Bank; and the InterAmerican Development Bank, which are all concerned with promoting the Economic Development of the Menber States.

In addition, we are members of the United Nations, the Commonwealth of Nations, the Organization of American States, and signatories to the Rio Treaty. In March of this year we will officially become members of the Non-Aligned Movement.

We have examined several hundred treaties and have taken action to become party to many of theni. These treaties regulate various aspects of international relations. The examination of treaties is a continuous and time-consuming process, especially in today's world where countries are forever trying to regulate and provide new rules on the solutions to new problems in the system.

Buman Rights

There are several Human Rights questions facing the intemational community today, but by far the most important is the question of Apartheid in South Africa. Afartheid is an Afrikaner word meaning "separateness - racial segregation". The South African whites followed this policy since the Dutch-speaking Afrikaners and the English-speaking elements joined to form the Union of South Africa in 1910. In 1948 Apartheid became official state policy.

What are some of the features of this abhorrent policy?
1) Group Areas Act 1966, which prohibits Africans from entering certain areas without a permit.

2) Bantu Land and Trust Act 1936, prom vides that $87 \%$ of the land 1 reserver for the white minority which constitutes $29 \%$ of the total population, while the remaining $13 \%$ is 'reserved' for Africans who constitute $68 \%$ of the popluation.

3) The Prohibition of Mixed Marriage Act 1949 , makes marriage between whites and non-whites illegal. Thus if a white man and a black woman are lawfully married outside South Africa, their marrtage is void and of no effect in South Africa. If a couple of different race cohabit in South Africa, be they Africans or visitors, they become liable to prosecution under the Immorality Act 1957.

4) Bantu Building Workers Act 1951 prohibits Africans from doing skilled work in the building industry in any town in White South Africa, but at the same time it allows a white man to be employed in skilled work in a Bantu Village as a supervisor of Africans. The Bantu Consolidation Act 1945 enpowers the labour officers at any time to terminate the employment of Africans regardless of how long they were working and regardless of whether or not they oppose the termination.

Needless to say, Africans do not vote. I can go on and on, but as you can see, this practice pervades every aspect of societal life in South Africa.

For a Long time the South African Government was able to prevent the Unted Nations from dealing with this issue by invoking Article 2 paragraph 7 of the United Nations Charter which states:-

"Nothing contained in the present Charter shall authorize the United Nations to intervene in matters which are essentially within the domestic jurisdiction of any state or shall require the menters to submit such matters to settlement under the 


\section{present charter....."}

However, the Increase in Thixd World membership buoyed by the Ethiopia-Liberia case before the International Court of Justice (Ethiopia took South Africa to the ICJ) in 1960 caused a change and resultant United Nations intervention.

The South African Government is determined to pursue 1 ts racist doctrine "in deflance of all International sanctions by creating what they call Bantu Stans - Independent States in South Africa". The International Community has refused recognition of these so-called States. Speaking about these Independent States, in 1978 the South African Minister of Bantu Administration and Development Mr. C. P. Mulder, said, and I quote - "If our policy is taken to its full logical conclusion, as far as the black man is concerned, there will not be one black man with South African citizenship" - end of quote.

The Government of The Bahamas strongly condemns this practice which is an affront to human dignity, and we have consistently done so in all international fora. We have supported the numerous resolutions on this matter and have contributed to several established funds for the purpose of providing food, clothing, education and shelter for these people. The Bahamas became a party to the Convention on Apartheid and has given its solemn obligation to do whatever it can to eliminate this affront to human dignity from the international system. Perpetrators of this policy are not welcomed to come to The Bahamas.

Decisions against Apartheid have also been taken in the Commonwealth Forum, particularly in the area of sports. In 1977 The Gleneagles Agreement came into being, which reaffirmed Commonwealth Governments' total opposition to Apartheid and called on them to undertake every practical step to discourage all sporting links with South Africa. The Bahamas is a party to that understanding. You may therefore understand the Caribbean and African Governments' reactions when it was learnt that a renegade West Indian team of cricketers had left to play in South Africa. The coming of the West Indian has been hailed in South Africa as the greatest coup $d^{\prime} e^{\prime}$ tat in recent sporting history. The Bahamas condemns this action on the part of these sportsmen.
Of course, they will not be allowed to participate in any official events in The Bahamas, nor will the Government support Bahamians or local teams which participate il any way with South African teams.

In adition, the human rights of the people of Namibia are continually violated. The racist regime in Pretoria continues to decry the inalienable rights of the people of Namibia to self-determination. We have altrays supported the independence movement in Namibia and hope that the Contact Group will continue its efforts to bring about the independence and territorial integrity of Namibia. If sanctions are necessary, we will certainly support them.

\section{Threats to International Eeace and Security}

There are several areas of conflict in certai: regions of the world. Perhaps the most serious is the Middle East.

The problem between the Israelis and Palestinians has a long and complex history and in order for you to understand why our policy. is what it is, I will give you a brief historical background. It involves the struggle for a sacred plece of real estate, but, as a former Ambassador of Saudi Arabia once said, "God is not in the real estate business".

The origins of the Palestine problem as an intemational issue developed out of events occurring toward the end of the first world war. Falestine was placed under the administration of the United Kingdon as a mandated territory. In principle, the mandate was meant to be in the nature of a transitory phase until Palestine attained the status of a fully independent nation. But, as we have seen, the mandate's historical evolution did not result in the emergence of Palestine as an independent nation.

During the period of the mandate, the zionist organization worked to secure the establishment of a Jewish national homeland in Palestine. The indigenous people of Falestine who had inhabited the land for virtually the two millennia, felt this movement to be a violation of their natural and inalienable rights. They also viewed it as an infringement of the assurances of independence given by the allied powers to Arab leaders in return for their support during the war. The result was mounting resisterce to the mandate 
by Palestinian Arabs followed by resort to violence by the Jewish Community as World War II ended. After a quarter of a century of the mandate, the United Kingdom submitted what had become "the Palestinian problem" to the United Nations on the basis that the mandatory power was faced with conflicting obligations that had proven Irreconcilable.

After examining various alternatives, the United Nations proposed the partitioning of Palestine into two independent states, one Palestinian Arab and the other Jewish with Jerusalem internationalized. The partition plan did not bring peace to palestine and violence erupted into a Middle East War which ceased only after United Nations intervention. One of the two states envisaged in the partition plan proclaimed $i t s$ independence in 1948 as Israel, and, in a series of successive wars, its territorial control expanded to occupy virtually all of Palestine. The Palestinian Arab State, envisaged in the partition plan, never materialised. The Palestinian problem quickly widened into the Middle- East ispute between Arab States and Israel, and from 1948 there have been wars and destructions forcing millions of Palestinians into exile and engaging the United Nations in an ongoing search for a solution to a problem which potentially is a grave threat to international peace and security. World opintion has recognized that lasting peace could only result when the inalienable rights of national self-determination is restored to the Palestinians.

The Bahamas thus supports the view that the Palestinians have an inalienable right to a homeland and also that the people of Is rael have a right to exist in peace. The Bahamas condemned in the strongest possible terms the mass muxders of innocent men, women and children in the Refugee Campus of Satra axd Shatila, and joined in the call by the Internaitonal Community for an enquiry into those atrocities. You might have heard recently that a commission of inquiry charged that the Israeli Minister of Defence bore some degree of responsibility and he has since been fired and replaced by Mr. Moshe Arens, who only last month presented his credentials as Israels's Anbassador to The Bahanas.

We subscribe to three important principles of international law, namely, (1) annexation of territory by force, (2) the use of force to settle disputes and (3) the inalienable right of all peoples to self-determination. It is our view that Israel has violated all three of these principles; it has used force to settle disputes (as has also the P.L.O.); it has anneyed the West Bank, Gaza and the Golan Heighis by force in the 1967 war, and is at tempting to change the demographic composition of the occupied territories by illegally creating settlements", and it has deliberately prevented the Palestinians from achieving independence. In spite of Israel's security arguments, the Palestinians have an inalienable right to self-determination

Nearer home, we have conflicts in Latin America. Of particular note are the conflicts between Belize and Guatemala and Guyana and Venezuela.

In the case of Belize, Guatemala clalmed the entire territory of Belize. An agreement was signed in March 1981 in which a framework for settlement was worked out. Guatemala, however, has chosen to disregard this agreement and instead wants an entire territory of Belize. We have supported Belize for a long time; in fact, our Prime Minister was cochairman of a Commonwealth Comittee dealing with this matter. We feel that the sanctity of agreements as a matter of principle must be upheld.

In the case of Guyana and Venezuela, the dispute was settled by an Arbitral Award in 1899. However, Venezuela has declared that award null and void and has reasserted its claim to $1 / 5$ of Guyana's territory, i.e., the Esiquibo Region. The Bahamas" position is that a Judicial settlement has already been found under international law. We have urged Venezuela to respect the territorial integrity of Guyana and have called on both parties to arrive at a peaceful solution under the principles and purposes of the Charter of the United Nations.

The most recent serious conflict in this region was the Falklands Dispute. The Bahamas supported the British in this conflict as it was felt that the use or threat of use of force in international relations, the principles of sovereignty, independence, territorial integrity and the non-interference in the indispensable norns of international behaviour which must be respected by all. Our decision to support the United Kingdom, Belize and Guyana was based on the sanctity of international law and the principles outlined above.

\section{Disarmament}

This issue has a long and varied history and we have taken a frontine position on this issue.

Our main concerns are that the increasing availability of these dangerous weapons of 
mass destruction poses tile single most serious threat to the peace and security

* of mankind. In a nuclear conflict mankind. is the loser. We cannot justify the wanton wastage of precious resources while there are serfous economic problems - poverty, hunger and underdevelopment - that face so many nation states of the world. Common sense demands a redirection of these valuable Resources. The Bahamas has urged all States to ensure that armaments meet legitimate security concerns. We also realise that peace can only be assured if there is a balance of power. We are a party to several important treaties on this subject among them are the Treaty of Tlatelolco which deals with the ron-proliferation of nuclear weapons in the region and Treaty on the non-proliferation of nuclear weapons. The Bahamas also unreservedly supports the Declaration of Latin America, including the Caribbean as a Zone of Peace.

With respect to Disarmament, we have served as Vice-Chalrman of the UN Tenth Special Session on Disarmament, as Chairman of the First Committee (Political and Securfty) of the UN and on the UN Comission on Disarmament. We have always supported any move which would assist in the achievement of general and complete disaramament.

\section{Irug Trafficking}

I now turn to the serious problem of Drug Trafflcking. There are several treaties regulating narcotic drugs to which The Bahamas is a party. The problem of drug abuse is a universal one and over the past several years, the Latin American Region has become the object of a new focus by international drug traffickers as the productien of and trafficking primarlly in Cannibis, Hashish, Cocaine and Methaqualone have significantly increased. The Bahamas is a major condult for the illicit traffic moving from source and supply centres in the Caribbean and South America to large and profitable markets in North America and Europe. We are concerned that small transit states like The Bahamas spend millions of dollars to fight this problem over which we have little or no control.

We have piloted through the 36 th and 37 th Sessions of the General Assembly Resolutions $36 / 132$ and $37 / 198$ dealing with trafficking of narcotic drugs with spectal emphasis on the transit states. We have pursued and have been elected to membership on the UN
Comnission on Narcotic Drugs, a forum through which we can let the International Comunity know the extent of the problem we face. The Bahamas has decided to host a UN Seminar for the English Speaking Caribbean in March of this year dealing with the problems of narcotic drug trafficking in the Caribbean subregion. We have also taken some bilateral actions with our neighbours which would increase the effectiveness of this campaign against international drug trafficking.

We have called for the assistance of our neighbours to help us in ridding our country of this disease over which we have very little control. We have received some assistance but not nearly sufficient to cope with the extent of the problem. Hopefully, the up-coming Seminar will focus greater attention to the problem and that greater assistance would be forthcoming.

The Organization of American States (OAS)

The Eahamas is a member of the OAS which acts as a regional body of the United Nations under Article 52 of the Charter. Joining would enable us to develop closer relations with Latin America and first and foremost it fulfils a major part of the security interests of The Bahamas. By virtue of joining the oks and affirming its principles, the collective Security Provisions which provide for defence and security against external aggression. As signatories to the Rio Treaty, our defence against outside aggression is secured.

Non-Aligned Movement

The Bahamas has applied for membership of the Non-Allgned Movement. This Movement was officially founded in 1961 although its beginning took place in Bandung 1955. It consists of small and medium sized states from the developing world. The principles which have united this Movement from its inception are: a commitment to peace and disarmament - especially the reduction of tensions between the major powers; the right of equality between all races; an interest in restructuring the existing international economic order - especially to restructure the growing inequality between the rich and poor nations; a need for restructuring the existing world order in the realm of information since the Movement is opposed to cultural imperialism and a monopoly of information systems; and finally the NAM has constantly sought to utilize the UN System as the most appropriate organization to deal with global issues and, hence, has resisted any efforts at instutionalising its own Movement at the expense of the United 
Nations.

The Bahamas has already identified itself with many of these principles and thus it has no doubt that it can make its contribution to the solution of global problems.

\section{Law of the Sea}

The Law of the Sea Convention was signed on Montego Bay, Jamaica on 10 December, 1982 by some 121 States including The Bahamas.

The Convention marks a milestone in the history of international cooperation and indeed it has been described as the single most successful endeavour ever attempted by civilised nations. Its achievements represent the balancing of the interest of Coastal States, Landlocked States, Archipelagic States, developed and developing States. If it has been critised as not meeting all of the objectives of a particular State, then this, to those who negotiated in the good faith of the consensus objective of the Conference, should be understood. For, in a multilateral Ireaty-Making Convention in which more than 160 States participated, it would have been an impossibility to satisfy the interest of all States; rather what was desirable was an accommodation though not entirely satisfying individual aspirations which one could live with.

As early as 1972 in the Independence White Paper, The Bahamas stated its particular interests in the Law of the Sea Conference. These include:

i) The Archipelaglc method of delimination of the Territorial Sea formulated in such a manner that the Great and Little Bahama Banks would be included in the areas subject to Bahamas juris. diction.

ii) A 12 mile territorial sea.

iii) A 200 miles Exclusive Economic Zone.

iv) A more precise method for the determination of the limits of the Continental Shelf.

v) Generally acceptable international rules for the prevention, reduction and control of pollution of the maxine environment from ships. vi) The creation of international machinery which will administer, explore and exploit the resources. of the benefit of mankind and in particular, the Peoples of the Developing World.

Let me briefly indicate to you the reasons for our interest in some of these specific items.

The Archipelago

The definition of the national boundaries of The Commonwealth of The Bahamas have not been satisfactorily defined.

In the Colonial era The Bahamas (Alteration of Boundaries) Order in Council $1948 \mathrm{did}$ attempt a definition of the Boundaries of the Colony of The Bahamas. According to that Order in Council the Boundaries of the colony were extended to include the area of the Continental Shelf which lies beneath the sea continguous to the coasts of The Bahamas. The application of this order would certainly have included the Great and Little Bahama Banks.

The 1958 and 1960 Conferences on the Law of the Sea left vague the limits of the territorial sea and did not at all treat the problem of Archipelagic States. The rule, though without an agreed limit, was that each island has its own territorial sea. For Archipelagos like The Bahamas, this meant that territorial sea limits would be measured around each island resulting in an untidy Mosaic of Arc and Circles interspersed with areas of high seas in between where drug traffickers may retreat whenever threatened by law enforcement officers within territorial waters.

Many years have elapsed since the 1945 order and the 1958-1960 Conferences. During this time the international community has undergone many changes of a profound nature. Not only has its membership become enhanced because of the decolonisation process, but it has become increasingly clear to the International Communty that in the interest of equity, adjustments to the Legal Regime of Seas had to be made to accommodate the legitimate interests of all the members of the international community, if order rather than chaos were to prevall. 
After 5 years of Preparitory Work the Law of the Sea Conference met for its first session in Decentuer 1973. The objective of the Conference was to prepare a new Convention that will better serve the interest of the international comounity.

The Bahamas attended the ten sessions of the Conference since this initial one. The Conference has endorsed the Archipelagic concept of delimitation.

The Convention would permit The Bahamas to draw baselines around the entire perimeter of the Archipelago including the Great and Little Bahama Banks and the Cay Sal Bank. The area of water thus enclosed would be approximately 80,000 square natical miles. The land area would include those areas above water and the submerged area of the Banks - some 38,382 square Nautical Miles. Yes, Ladies and Gentlemen for The Bahamas, in relation to the drawing of Archipelagic baselines, the Convention has turned water into land. In order to qualify as an Archipelago, under the terms of the Convention, the area of Land to the area of Water enclosed had to fall within specified ration.

A Clause in the Convention which was especially negotiated so as to allow the Bahamas to include the Banks formation in the Archipelagic enclosure reads as follows:-

"For the purpose of computing the ratio of water to Iand, Iand areas may include waters lying within the fringing reefs of islands and atolls, including that part of a steep-sided oceanic plateau which is enclosed or nearly enclosed by a chain of limestone is lands and drying reefs lying on the perimeter of the plateau.

The water enclosed by the Archipelago would be subject to Bahamas Sovereignty notwithstanding that the traditional freedoms of navigation and cverflight would prevail in the sealanes and air corridors that traditionally harboured such usage. We could not have accomplished this without the co-operation of some of the major martime powers for which we are indeed grateful.

All other martitime regimes, i.e. the territorial sea, the exclusive economic zone would be measured seaward of the Archipelagic baselines. The effect of this would be to further enhance the size of the area of Bahamian jurisdiction, proximity to neighbouring states, permitting in these areas.

The largest part of the Convention and the one to which the Conference devoted more of $i$ ts time than to any other, concerns the future regite for exploring and exploiting the bottom of the deep ocean in areas beyond the continental shelf of any state. Of main economic interest in this area at present are polymetallic nodules lying on or just below the seabed. These nodules contain manganese, copper, nickle and cobalt.

The Convention would establish a "parallel system" for exploring and exploiting these minerals. Under the system all activities in the area would be under the control of the International Seabed Authority which is to be sited in Jamaica. The Authority would be authorised to conduct its own mining operations through an organ called, the Enterprise. At the same time, the Authority would contract with private and state ventures to give them mining rights in the area, so that they can operate in parallel with the Authority. The resources of the area would be managed as a "Common Heritage".

Certain industrialised nations, including the Urited States, did not sign the Convention and there has been talk of them unilaterally conducting seabed mining activities outside the framework of the Convention. The reasons why these nations are hesitant to become associated with the treaty relate mainly to the transfer of mining technology to the Authority, the Limitations on the annual production of minerals and representation on the Council of the Authority.

The lawfulness of such attenpts, in our view would be called into question, and would, I submit be ample justification for a request by the General Assenbly of the United Nations to the International Court of Justice for an advisory opinion.

There is one matter of strategic interest which we as a people must understand. The Bahamas is a sovereign, free and independent State. That is of supreme importance in the conduct of our Foreign Affairs. As a free independent and sovereign state, the interest of The Bahamas must always be paramount. We must at all time pursue a policy which eninance our independence, sovereignty and territorial integrity. These are not negotiable. It is the interest of The Bahamas first, second and always. While we will continue to operate with due consideration for the normal and 
customary conduct of diplomacy, the interest of The Bahamas must supercede all other nations, but remain their friends. However, as with other States, we must preserve the independence and territorial integrity of The Bahamas. Any action by others which violate our sovereignty will be met with the appropriate condemnation. On our part we will continue to respect the territorial integrity and independence of all states and will continue to abide by the accepted rules of diplomacy. We only require the same of others and to be left alone in the pursuit of our goals. We do not wish to be dominated or coerced and will not accept any attempt, however camouflaged, to interfere in our internal affairs. We hope that all Bahamians will stand by us in this noble objective of preserving The Bahamas.

\section{World Economic Crisis}

The Bahamas, Iike all other countries, is affected by factors operating in the International Community. The World Economy continues to be caught in the most severe recession since the great depression of the 1930s. The percapita GNP for developing countries as a whole has fallen for the first time since the 1950s. The present downward spiral follows two decades of exceptional growth and development in both industrialised and developing countries, but now there are serious doubts with respect to the prospects for growth during the rest of the decade. The concern of governments with immediate domestic problems has intensified, protectionist tendencies have reemerged, recession, inflation and high interest rates in the developed countries have had an adverse impact on Tourism, Financial and Technological Resources flows, especially foreign direct investments to the developing countries. Negotiations are presently underway to find a framework to redress the structural imbalances in the world economy, particularly in the areas of trade, raw materials, energy, money and finance. The developed world must realise that total recovery and the survival of their own economies depends on survival of the economies of the developing world. This interdependence makes it mandatory that international economic cooperation on all issues must be accomplished. 